\title{
Spatial distribution and risk assessment of heavy metals in bottom sediments of two small dam reservoirs (south-east Poland)
}

\author{
Halina Smal ${ }^{1 *}$, Sławomir Ligęza¹, Anna Wójcikowska-Kapusta¹, Stanisław Baran¹, Danuta Urban¹, \\ Radomir Obroślak², Artur Pawłowski ${ }^{3}$ \\ ${ }^{1}$ University of Life Sciences in Lublin, Poland \\ Institute of Soil Science, Environment Engineering and Management \\ ${ }^{2}$ University of Life Sciences in Lublin, Poland \\ Department of Environmental Engineering and Geodesy \\ ${ }^{3}$ Lublin University of Technology, Poland \\ Faculty of Environmental Engineering \\ *Corresponding author's e-mail: halina.smal@up.lublin.pl
}

\begin{abstract}
Keywords: sediment, dam reservoir, heavy metals, spatial distribution, sediment quality, sediment dredging.
Abstract: Sediments of two dam reservoirs in SE Poland, Zalew Zemborzycki (ZZ) and Brody Iłżeckie (BI) were studied. The sediments from both reservoirs were sampled in the transects perpendicular to the shoreline, at the river inflow and the frontal dam. The total concentration of $\mathrm{Mn}, \mathrm{Zn}, \mathrm{Pb}, \mathrm{Cd}, \mathrm{Cu}, \mathrm{Cr}$ and $\mathrm{Ni}$ was determined by ICP-EAS method after the sample digestion in the mixture of concentrated $\mathrm{HNO}_{3}$ and $\mathrm{HClO}_{4}$ acids. The statistical analyses: value intervals, mean values, variation coefficient, the median and the skewed distribution were performed. To estimate differences between the means for transects, Tukey`s test was applied with least significant difference (LSD) determination. The maps of the metal spatial distribution were drawn and sediment quality according to the geochemical and ecotoxicological criteria evaluated. Differences between the reservoirs in terms of heavy metals concentration in bottom sediments, and regularities in their spatial distribution were found. In the ZZ sediments the concentration was at the level of geochemical background $(\mathrm{Zn}, \mathrm{Cr})$, slightly $(\mathrm{Cd}, \mathrm{Cu}, \mathrm{Ni})$ or moderately $(\mathrm{Pb})$ contaminated sediments. The metal concentration in the sediments of the BI was up to eight times higher as compared to the ZZ. Moreover, sediments from the BI reservoir showed a greater variability of metal concentration than those from $\mathrm{ZZ}$, which resulted from the dredging operation performed in the part of the reservoir. Metal concentration in sediments of the dredged part was ca. 2-5 times lower than in the undredged one, which indicates that after the dredging operation, accumulation of these metals was slight. The concentrations of $\mathrm{Zn}, \mathrm{Pb}$ and $\mathrm{Cd}$ from the undredged part of $\mathrm{BI}$ were at the level of contaminated sediments and exceeded the probable effects level (PEL). In the ZZ, the greatest accumulation of metals occurred in the upper part of the reservoir and at the frontal dam, and the lowest in the middle part of the reservoir. In BI, the lower outflow of water in this reservoir caused a lower metal concentration in the sediments at the frontal dam, as compared with the other sediments in the undredged part of the reservoir. The results indicate that in small and shallow reservoirs, areas of accumulation of heavy metals depend on such factors as a parent river current, reservoir depth, water waving, reservoir shape (narrowing, coves/bays), and type of water outflow.
\end{abstract}

\section{Introduction}

Sediments constitute an integral part of aquatic ecosystems, as they provide a habitat for numerous aquatic organisms to grow and develop (Kajak 1998, Bojakowska and Gliwicz 2005). They are a storage site for various kinds of substances, including heavy metals (Salomons and Förstner 1984, Korfali et al. 2006). Heavy metals do not degrade biologically like organic contaminants, but they are persistent and accumulate in sediments being bound by the sorptive complex. In an aquatic environment, sediments represent both a major repository and an internal source of metals (Dang and Jeffry 2006, Zhang et al. 2013, Zhu et al. 2013).
Metals are considered a reliable indicator of aquatic ecosystem health. Being accumulated in sediments, owing to their mobility and bioavailability, they have a potential ecotoxic impact and pose hazards for the ecosystem (Salomons and Förstner 1984, MacDonald et al. 2000, Demirak et al. 2006, Jabłońska-Czapla et al. 2014). Metals are likely to accumulate in microorganisms as well as plant and animal aquatic organisms, which in turn may enter the human food chain and, subsequently, affect human health (Loska and Wiechuła 2003, Demirak et al. 2006, Kostecki 2007).

Metal concentration in sediments reflects the geological structure of the catchment and anthropogenic input 
(Arnason and Fletcher 2003, Manasreh et al. 2010, Li et al. 2012, Wang et al. 2015). The metals in sediments come from the catchment via fluvial transport, atmospheric deposition and/or municipal wastewater and industrial sewage (Demirak et al. 2006, Aleksander-Kwaterczuk and Helios-Rybicka 2009, Ciszewski et al. 2012).

Binding of heavy metals by sediments depends on their grain-size distribution (clay fraction), organic matter content and also Fe, Al and Mn oxides (Kostecki and Kowalski 2007, Gierszewski 2008, Çevik et al. 2009, Sojka et al. 2013, Ibragimow et al. 2013).

Concentration of particulate-bound analytes relies more on the hydrodynamic conditions governing the sediment deposition than on proximity to contaminant sources (Campbell et al. 1988, Akhurst 2012, Huang et al. 2012). Hydrological conditions, especially changes in water flow velocity on the dammed river part, constitute an important factor contributing to varied heavy metal contents in sediments (Leńczowska-Baranek 1996, Gierszewski 2008). Although a vast body of research has been conducted on sediments in water reservoirs, few studies have focused on the spatial distribution and pollution assessment of heavy metals in sediments.

Large amounts of toxic substances, including heavy metals, occur in sediments of reservoirs constructed on strongly contaminated rivers (Loska and Wiechuła 2003, Aleksander-Kwaterczuk and Helios-Rybicka 2009, Ciszewski et al. 2012). In contrast, sediments from reservoirs whose river catchment is located at the agriculture-forest or non-industrial area contain metals at the geochemical background level or are only slightly contaminated (Bojakowska and Sokołowska 1998).

The studies on sediment quality provide useful information on the contamination level of a reservoir. Assessment of the chemical quality of bottom sediments not only indicates the state of the aquatic environment but also serves as the basis for development of sediment management strategies in the environment or sediment disposal (Darmody and Marlin 2002, Dmitruk et al. 2013). Hence, evaluation of heavy metal content in sediments is of primary importance.

Evaluation of bottom sediment quality in terms of pollution with harmful organics and trace elements is made on the grounds of, among others, geochemical criteria. In Poland, geochemical classification according to Bojakowska and Sokołowska (1998) is used. Sediments are also evaluated using the index of geoaccumulation (Igeo) and the enrichment factor (EF) (Çevik et al. 2009, Wang et al. 2012, Hu et al. 2013). There are also applied ecotoxicological criteria such as Threshold Effects Level (TEL) and Probable Effects Level (PEL), or Threshold Effect Concentration (TEC) and Probable Effect Concentration (PEC) (MacDonald et al. 2000), based on a particular contaminant's impact on aquatic organisms.

The paper presents the results concerning heavy metals in bottom sediments of two small dam reservoirs in Southern-Eastern Poland: Zalew Zemborzycki (ZZ) and Brody Iłżeckie (BI). The objective of the paper was (i) to determine a concentration and spatial distribution of heavy metals in bottom sediments of ZZ and BI reservoirs and factors such as the reservoir morphometry, type of water outflow and dredging operation, affecting them, (ii) to assess sediment quality, considering metal concentration according to the geochemical and ecotoxicological criteria.

The reservoirs are of comparable area and serve similar functions. They are characterized by different water outflow systems - top in the $\mathrm{ZZ}$ while lower in the BI, which allows determining the effect of this factor on concentration and spatial distribution of heavy metals in the sediments.

Importantly, since the $\mathrm{ZZ}$ became operational, no works have been performed that could disturb the mass of sediment deposition. As for the BI reservoir, it was rebuilt in the second half of the 1980s. The redevelopment efforts included the dam reservoir rebuild and complete sediment load removal from the considerable part of the reservoir. Therefore, the Brody Iłżeckie reservoir gives a possibility to determine the effect of dredging operation on the concentration and spatial distribution of heavy metals in the sediments.

Also, the reservoirs differ in terms of pollution sources. The major contaminant sources of Zalew Zemborzycki are direct discharges of wastewater to the Bystrzyca River and its tributaries from six municipal wastewater treatment facilities. The Bystrzyca river catchment area above the $\mathrm{ZZ}$ is also under severe pressure from agricultural land, which creates diffuse sources of pollution. The most important pollutant source of the Kamienna River above the Brody Iłżeckie dam reservoir and the reservoir itself is wastewater coming from three wastewater treatment plants. Two of them, i.e. in Starachowice and Skarżysko-Kamienna have the greatest effect on surface water. It should be pointed out that the wastewater treatment plant in Skarżysko-Kamienna releases both municipal and industrial treated sewage, as in recent decades metallurgical, energy, footwear and railroading industries have prevailed in this region. However, currently these industry branches have a diminished economic significance in favor of the small/ medium business sector.

\section{Study area and methods}

The location of the study area and the dam reservoir characteristics are shown in Fig. 1 and in Table 1, respectively. The reservoirs control water flow, provide recreational opportunities and are used by industry only to a small degree. The BI reservoir supplies water to the industrial plants in Starachowice, while the ZZ feeds water to the Wrotków Thermal Power Plant in Lublin. In the Brody Iłżeckie reservoir the dredging operation was performed in the area of IV and V sector (Fig. 1b).

\section{Sediment sampling}

The bottom sediments from both reservoirs were collected in July 2010 by means of the Kajak sediment core sampler (Kajak et al. 1965). In both reservoirs, the material was taken from 17 sampling sites. For the $\mathrm{ZZ}$ reservoir, the following sampling points were used: 4 samples from each of three transverse transects, i.e. in the upper (B), middle (C) and lower (D) part of the reservoir, one sample from the Bystrzyca inflow site (A) and one from the frontal dam (E) (Fig. 1a). Additional single samples were taken from the bay parts of the reservoir, between $\mathrm{B}$ and $\mathrm{C}$ transects $(15)$, and between $\mathrm{C}$ and $\mathrm{D}(16,17)$. In the $\mathrm{BI}$ reservoir, 13 samples were collected in four transverse transects (IV,V,VI,VII, 2-4 samples each, depending on the transect length), three samples from the part of the Kamienna River inflow (I1, II2, III3) and one sample from the frontal dam (VIII17) (Fig. 1b). At each sampling point, 10-15 hydrated sediment cores were taken to form the composite sample (ca. $5 \mathrm{dm}^{3}$ ). The sediments were air-dried without water removal, 


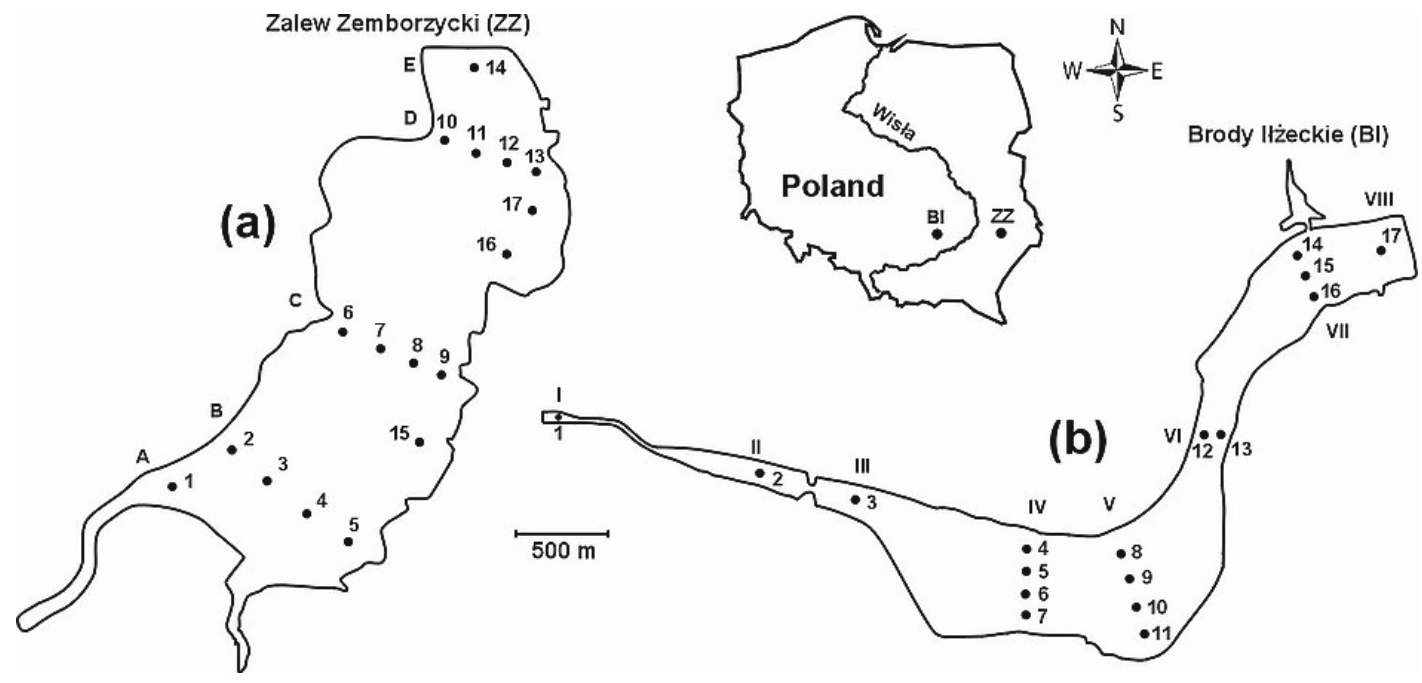

Fig. 1. Location of study area and sediments sampling sites in the reservoirs: Zalew Zemborzycki (a) and Brody lłżeckie (b)

Table 1. Reservoir characteristics

\begin{tabular}{|c|c|c|}
\hline Feature & Brody lłżeckie $(\mathrm{BI})^{\mathrm{a}}$ & Zalew Zemborzycki (ZZ) \\
\hline Year of construction & 1964, 1986 dam rebuilding & 1974 \\
\hline Location & N5100’13”, E2110’01” & N5110’43”, E22³1’25” \\
\hline River & Kamienna & Bystrzyca \\
\hline Frontal dam & $83.6 \mathrm{~km}$ of the river & $32.9 \mathrm{~km}$ of the river \\
\hline Surface areac & 204 ha & 282 ha \\
\hline Length & $6.2 \mathrm{~km}$ & $2.9 \mathrm{~km}$ \\
\hline Maximal width & $750 \mathrm{~m}$ & $1330 \mathrm{~m}$ \\
\hline Volume $^{c}$ & $7.6 \mathrm{mln} \mathrm{m}^{3}$ & $6.34 \mathrm{mln} \mathrm{m}^{3}$ \\
\hline Maximal (mean) depth & $6 \mathrm{~m}(2.9)$ & $4 \mathrm{~m}(2.2)$ \\
\hline Maximal level of damming & $195.0 \mathrm{~m}$ above sea level & $178.5 \mathrm{~m}$ above sea level \\
\hline Mean water flow & $3.05 \mathrm{~m}^{3} \mathrm{~s}^{-1}$ & $2.81 \mathrm{~m}^{3} \cdot \mathrm{s}^{-1}$ \\
\hline Water retention & 29 days & 26 days \\
\hline
\end{tabular}

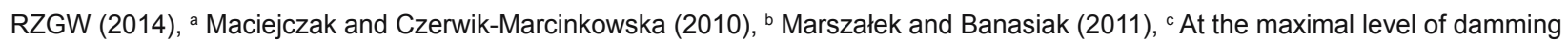

passed through a $2 \mathrm{~mm}$ sieve and homogenized in an agate mortar. The bulk sample size was analyzed.

\section{Methods}

The sediment samples were examined to measure a concentration of $\mathrm{Mn}, \mathrm{Zn}, \mathrm{Pb}, \mathrm{Cd}, \mathrm{Cu}, \mathrm{Cr}$ and $\mathrm{Ni}$ using the ICP-EAS method (Lemans Inc. PS950 instrument), applied after the sample digestion (in two replicates), in the mixture of concentrated $\mathrm{HNO}_{3}$ and $\mathrm{HClO}_{4}$ acids $(1: 1 \mathrm{v} / \mathrm{v})$. Digestion was performed in the DKL 20 Fully Automatic Digestion Unit (VELP SCIENTIFICA). The reagents used in the analyses were analytically pure, and the water was deionized. The calibration curves and the concentration measurements were performed for each metal separately using the certified single element standards for ICP, manufactured by Inorganic Ventures (Lakewood, USA). Table 2 shows wavelengths and limits of detection in ICP-EAS method used.

The following statistical analyses were performed: value intervals (minimum and maximum), mean values, variation coefficient, the median and the skewed distribution. To estimate differences between the means for transects, Tukey`s test was applied with establishing the least significant
Table 2. Wavelengths and limits of detection in ICP - EAS method

\begin{tabular}{|c|c|c|}
\hline Element & Wavelength & Limit of detection \\
\hline & $(\mathrm{nm})$ & $\left(\mathrm{mg}^{\mathrm{k}} \mathrm{H}^{-1}\right)$ \\
\hline $\mathrm{Cd}$ & 214.438 & 0.000306 \\
\hline $\mathrm{Mn}$ & 257.610 & 0.020 \\
\hline $\mathrm{Zn}$ & 213.856 & 0.002 \\
\hline $\mathrm{Pb}$ & 220.353 & 0.030 \\
\hline $\mathrm{Cu}$ & 224.700 & 0.062 \\
\hline $\mathrm{Cr}$ & 206.149 & 0.014 \\
\hline $\mathrm{Ni}$ & 221.647 & 0.027 \\
\hline
\end{tabular}

difference (LSD). The statistical analyses were performed using the STATISTICA program (ver.10, Statsoft ${ }^{\circledR}$ ).

The maps of metal spatial distribution were made. In order to interpolate the distributions, the kriging technique was applied to provide optimal unbiased interpolation estimation for points and blocks. As the variables under study did not satisfy 
the stationary condition, they underwent a trend analysis. The detected trends were removed, and empirical semivariograms values calculated and fitted to the mathematical functions used to estimate the studied values in the space by means of an ordinary kriging procedure. The analyses were performed based on the ArcGIS program.

Sediment quality in terms of heavy metal content was evaluated according to a geochemical criterion (Bojakowska and Sokołowska 1998) and ecotoxicological criteria (Smith et al. 1996, MacDonald et al. 2000).

\section{Results}

\section{Manganese}

Manganese concentration in the sediments of the Zalew Zemborzycki reservoir was in a wide range and showed differentiation subject to location within the reservoir (Tab. 3, Fig. 2a). Mean values in the sediments of transects $B, C$, and $\mathrm{D}$ were found within $109.5-147.3 \mathrm{mg} \cdot \mathrm{kg}^{-1}$ and the differences between them were not statistically significant.

Table 3. Total concentration of heavy metals in bottom sediments of Zalew Zemborzycki reservoir

\begin{tabular}{|c|c|c|c|c|c|c|c|}
\hline Transect, location /statistics & $\mathrm{Mn}$ & $\mathrm{Zn}$ & $\mathrm{Pb}$ & $\mathrm{Cd}$ & $\mathrm{Cu}$ & $\mathrm{Cr}$ & $\mathrm{Ni}$ \\
\hline \multicolumn{8}{|c|}{$\left(\mathrm{mg} \cdot \mathrm{kg}^{-1}\right.$ d.w.s. $\left.{ }^{\mathrm{a}}\right)$} \\
\hline $\mathrm{A} 1$ & 163.0 & 77.7 & 67.1 & 0.54 & 9.8 & 10.2 & 6.2 \\
\hline \multicolumn{8}{|l|}{$B$} \\
\hline Mean B & 147.3 & 46.9 & 51.8 & 0.53 & 8.03 & 8.3 & 7.0 \\
\hline CV\% ${ }^{\mathrm{b}}$ & 19.8 & 23.7 & 6.4 & 8.4 & 16.9 & 53.6 & 32.8 \\
\hline \multicolumn{8}{|l|}{$\mathrm{C}$} \\
\hline Mean C & 109.5 & 34.0 & 48.4 & 0.36 & 5.0 & 3.9 & 4.1 \\
\hline CV\% & 33.6 & 32.6 & 8.0 & 39.0 & 38.7 & 100.2 & 46.0 \\
\hline \multicolumn{8}{|l|}{$\mathrm{D}$} \\
\hline Mean D & 117.0 & 41,1 & 53.8 & 0.50 & 7.1 & 5.1 & 7.3 \\
\hline CV\% & 2.7 & 3.6 & 9.7 & 26.6 & 4.4 & 78.2 & 20.0 \\
\hline E14 & 134.0 & 34.6 & 58.3 & 0.62 & 6.6 & 2.1 & 5.6 \\
\hline 15 & 118.0 & 38.8 & 57.6 & 0.47 & 7.2 & 2.8 & 6.4 \\
\hline 16 & 128.0 & 55.4 & 61.9 & 0.75 & 6.8 & 9.6 & 5.1 \\
\hline 17 & 133.0 & 38.6 & 61.1 & 0.58 & 7.2 & 6.7 & 6.9 \\
\hline Overall minimum & 60.8 & 24.1 & 42.7 & 0.23 & 3.0 & 0.1 & 1.4 \\
\hline Overall maximum & 190.0 & 77.7 & 67.1 & 0.75 & 9.8 & 14.1 & 9.5 \\
\hline Overall mean & 128.0 & 43.1 & 54.2 & 0.50 & 7.1 & 5.9 & 6.1 \\
\hline CV\% & 20.9 & 29.6 & 11.5 & 26.50 & 22.6 & 66.9 & 31.7 \\
\hline $\operatorname{LSD}^{\mathrm{c}}(\mathrm{B}, \mathrm{C}, \mathrm{D})$ & 53.64 & 17.95 & 8.32 & 0.227 & 2.90 & 8.16 & 3.80 \\
\hline Median & 127.0 & 41.0 & 52.0 & 0.5 & 7.2 & 4.5 & 6.2 \\
\hline Skewness & -0.1 & 1.3 & 0.8 & -0.6 & -0.7 & 0.5 & -0.2 \\
\hline
\end{tabular}

a d.w.s. - dry weight of sediment, ${ }^{b} \mathrm{CV}$ - coefficient of variation, ${ }^{\mathrm{c}} \mathrm{LSD}$ - the least significant difference

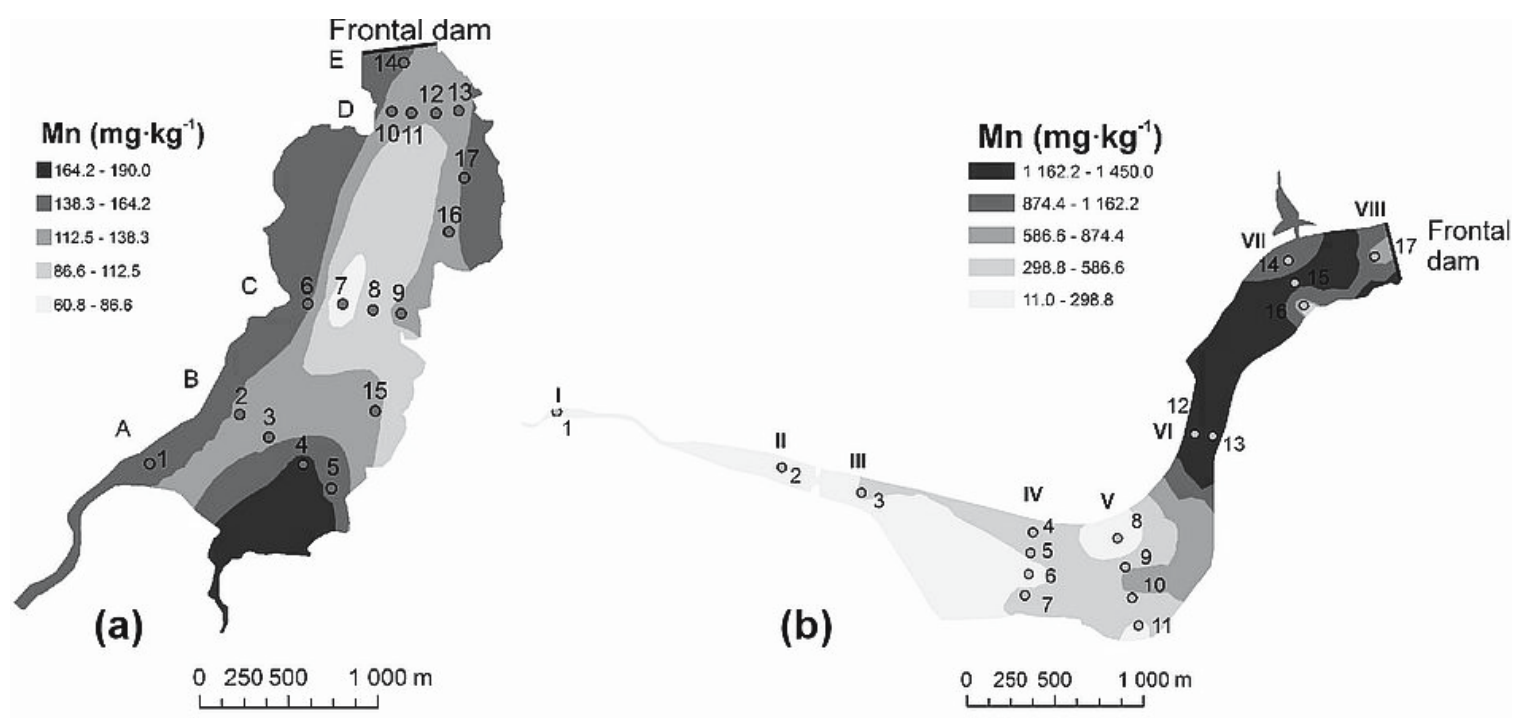

Fig. 2. Spatial distribution of Mn in bottom sediments of the reservoirs: Zalew Zemborzycki (a) and Brody lłżeckie (b) 
In most samples $(\mathrm{n}=11)$, Mn concentration was within the $112.5-138.3 \mathrm{mg} \cdot \mathrm{kg}^{-1}$ range (Fig. 2a), where mean values for the reservoir and median were also found (Tab. 3). Three samples displayed a level higher than the above range for this element, while the three intervals under the medium and highest values contained only one sample each. Consequently, manganese concentration distribution in the sediments of the Zalew Zemborzycki reservoir approached the near normal distribution $(\mathrm{As}=-0.1)$.

Analysis of manganese spatial distribution showed its lowest concentration in the sediments of the middle part of the $\mathrm{ZZ}$, within the transect $\mathrm{C}$ area, whereas the highest concentration was found in the upper part, in the southern and south-eastern (bay part) areas (Fig. 2a). Intermediate values were determined in the sediments from the lower part near the dam, and in the middle of the upper part of the reservoir.
In the Brody Iłżeckie reservoir, $\mathrm{Mn}$ level in sediments was found to be more varied in comparison to the ZZ (Tab. 4, Fig. 2b). The inflow part (I-III) plus one undergoing the sediment dredging treatment (transect IV and $\mathrm{V}$ area), hereafter referred to as the first part, differed markedly from the undredged one (hereafter referred to as the second part) in regard to Mn concentration in sediments. Mean Mn concentration in the sediments of the first part was $277.8 \mathrm{mg} \cdot \mathrm{kg}^{-1}$, and in the sediments of the second part it was nearly four times higher. The differences between the mean values of transect IV and V of the first part and VII of the second part were statistically significant (Tab. 4).

Manganese distribution in the sediments of the BI reservoir (Fig. 2b) demonstrated that its concentration in five samples was found within the lowest range values (11.0-298.8 $\left.\mathrm{mg} \cdot \mathrm{kg}^{-1}\right)$, in seven samples within the higher

Table 4. Total concentration of heavy metals in the sediments of Brody lłżeckie reservoir

\begin{tabular}{|c|c|c|c|c|c|c|c|}
\hline \multirow{2}{*}{ Transect, location /statistics } & $\mathrm{Mn}$ & $\mathrm{Zn}$ & $\mathrm{Pb}$ & $\mathrm{Cd}$ & $\mathrm{Cu}$ & $\mathrm{Cr}$ & $\mathrm{Ni}$ \\
\hline & \multicolumn{7}{|c|}{$\left(\mathrm{mg} \cdot \mathrm{kg}^{-1}\right.$ d.w.s. $\left.{ }^{\mathrm{a}}\right)$} \\
\hline \multicolumn{8}{|l|}{ I-III } \\
\hline Mean I-III & 128.9 & 122.5 & 41.8 & 0,88 & 6,9 & 13.87 & 2.13 \\
\hline$C V \%^{b}$ & 139.6 & 138.9 & 22.5 & 112.4 & 137.5 & 173.2 & 173.2 \\
\hline \multicolumn{8}{|l|}{ IV } \\
\hline Mean IV & 330.0 & 188.0 & 45.7 & 1.25 & 7.9 & 16.05 & 4.62 \\
\hline CV\% & 45.8 & 54.9 & 14.2 & 51.6 & 63.8 & 70.8 & 67.5 \\
\hline \multicolumn{8}{|l|}{$\mathbf{V}$} \\
\hline Mean V & 336.9 & 233.0 & 56.3 & 1.54 & 9.9 & 24.45 & 9.55 \\
\hline CV\% & 78.6 & 84.2 & 38.9 & 60.9 & 87.8 & 105.2 & 93.8 \\
\hline Minimum I-V & 11.0 & 21.4 & 36.3 & 0.31 & 1.3 & 0.01 & 0.01 \\
\hline Maximum I-V & 585.0 & 511.0 & 87.1 & 2.67 & 22.2 & 61.90 & 19.20 \\
\hline Mean I-V & 277.8 & 186.7 & 48.5 & 1.26 & 8.3 & 18.51 & 5.62 \\
\hline CV\% I-V & 75.1 & 80.7 & 30.3 & 64.7 & 84.7 & 104.7 & 113.2 \\
\hline \multicolumn{8}{|l|}{$\mathrm{VI}$} \\
\hline Mean VI & 1335.0 & 601.0 & 109.0 & 5.03 & 34.2 & 94.10 & 40.75 \\
\hline \multicolumn{8}{|l|}{ VII } \\
\hline Mean VII & 947.7 & 660.3 & 111.7 & 4.74 & 32.7 & 86.70 & 27.77 \\
\hline CV\% & 41.6 & 41.0 & 4.0 & 44.9 & 63.2 & 54.2 & 58.1 \\
\hline VIII17 & 771.0 & 635.0 & 89.9 & 3.50 & 24.4 & 52.10 & 15.80 \\
\hline Minimum VI-VIII & 493.0 & 348.0 & 89.9 & 2.33 & 9.1 & 33.1 & 9.2 \\
\hline Maximum VI-VIII & 1450.0 & 826.0 & 116.0 & 6.37 & 47.7 & 106.0 & 55.4 \\
\hline Mean VI-VIII & 1028.0 & 636.3 & 107.1 & 4.63 & 31.8 & 83.4 & 30.1 \\
\hline CV\% VI-VIII & 33.9 & 34.8 & 8.7 & 32.4 & 28.7 & 40.8 & 55.6 \\
\hline Overall minimum & 11.0 & 21.4 & 36.3 & 0.31 & 1.3 & 0.01 & 0.01 \\
\hline Overall maximum & 1450.0 & 826.0 & 116.0 & 6.37 & 47.7 & 106.0 & 55.4 \\
\hline Overall mean & 549.0 & 345.0 & 69.2 & 2.45 & 16.6 & 41.4 & 14.26 \\
\hline CV\% & 83.2 & 81.2 & 45.6 & 80.5 & 89.9 & 97.1 & 112.7 \\
\hline $\mathrm{LSD}^{\mathrm{c}}(\mathrm{IV}, \mathrm{V}, \mathrm{VII})$ & 548.27 & 387.39 & 28.61 & 2.571 & 24.27 & 58,87 & 20.09 \\
\hline Median & 441.0 & 288.0 & 52.7 & 1.9 & 10.0 & 23.2 & 6.7 \\
\hline Skewness & 0.7 & 0.7 & 0.4 & 0.8 & 0.9 & 1.0 & 1.4 \\
\hline
\end{tabular}

a d.w.s. - dry weight of sediment, ${ }^{\mathrm{b}} \mathrm{CV}$ - coefficient of variation, ${ }^{\mathrm{C} S S D}$ - the least significant difference 
interval (298.8-586.6 $\left.\mathrm{mg} \cdot \mathrm{kg}^{-1}\right)$ and in three samples within the highest interval $\left(1162.2-1450.0 \mathrm{mgkg}^{-1}\right)$. It shows a right-skewed distribution (As=0.7) (Tab. 4).

The analysis of manganese spatial distribution in sediments of the Brody Iłżeckie reservoir indicates a distinct division into two parts (Fig. 2b). In one part, i.e. the area up to and including transect V, Mn level was found to be within the two lowest intervals. In the other part, zones of higher Mn concentration occur in the sediments. At first, they are arranged parallel to the frontal dam, and then, in a slightly skewed direction within the VII16 and VIII17 location areas.

\section{Zinc}

The highest mean $\mathrm{Zn}$ concentration in sediments of Zalew Zemborzycki was established in the transect B sediments, with the lowest in transect $\mathrm{C}$ (Tab. 3). An intermediate mean value of the element was stated in the transect $\mathrm{D}$ sediments, in the lower part of the reservoir. Similar to Mn, the differences between the mean values for the transects were not statistically significant.

The greatest number of sediment samples had a $\mathrm{Zn}$ concentration from 34.8 to $45.5 \mathrm{mg} \mathrm{kg}^{-1}$ (Fig. 3a). The other samples showed values lower than those in the above interval $(n=3)$ or higher $(n=4)$. This is an apparently right-skewed distribution $(\mathrm{As}=1.3)$.

The map of $\mathrm{Zn}$ distribution displays its highest accumulation in sediments from the upper part of the $\mathrm{ZZ}$ reservoir, i.e. in the region of the river tributary and its south-western part (Fig. 3a). In this area, Zn level was observed to diminish in the zones arranged from west towards south-east. From the middle part of the reservoir, a different, longitudinal (perpendicular to the frontal dam) zonal arrangement occurs. The lowest $\mathrm{Zn}$ concentrations were reported in the sediments from the western part, while the values increase in the sediments advancing towards the eastern part.

In the $\mathrm{BI}$ dam reservoir, mean $\mathrm{Zn}$ concentration in sediments in the dredged part was $186.7 \mathrm{mgkg}^{-1}$, which was substantially lower in comparison to the undredged part (Tab. 4). It should be noted that mean $\mathrm{Zn}$ level in sediments of the $\mathrm{BI}$ reservoir was many times higher than in sediments from the $\mathrm{ZZ}$, in both the dredged part (4.3 times higher) and the undredged part (14.8 times).

Five samples of sediments from the BI were found in the lowest interval of $\mathrm{Zn}$ content $\left(21.4-182.3 \mathrm{mg} \mathrm{kg}^{-1}\right)$, the next five in the higher one and finally, three samples in the highest interval (665.1-826.0 $\left.\mathrm{mg} \mathrm{kg}^{-1}\right)$ (Fig. 3b). This is a slightly right-skewed distribution (As=0.7).

The $\mathrm{Zn}$ spatial distribution in the sediments of the $\mathrm{BI}$ reservoir was similar to the Mn distribution (Fig. 3b). This element concentration increased towards the frontal dam. In the lower part of the reservoir, attention is drawn to the locations VII16 and VIII17, where the sediments had appreciably lower levels of Zn content in comparison to locations VII14 and VII15.

\section{Lead}

Bottom sediments of Zalew Zemborzycki showed a slight differentiation in $\mathrm{Pb}$ concentration (Tab. 3). The average concentration for all of the sediments was at the $54.2 \mathrm{mg} \mathrm{kg} \mathrm{kg}^{-1}$ level at an $11.5 \%$ variation coefficient.

Most of the sediment samples obtained from the $\mathrm{ZZ}$ were found within the $\mathrm{Pb}$ value interval of 47.6 to $52.5 \mathrm{mg} \mathrm{kg}^{-1}$ $(\mathrm{n}=8)$ and 57.3-62.2 $\mathrm{mg} \cdot \mathrm{kg}^{-1}(\mathrm{n}=6)$ (Fig. 4a). In the extreme intervals, i.e. the lowest and highest values, only one sediment sample per interval was stated. As a result, the skewness coefficient was 0.8 .

The map of lead spatial distribution in the sediments in the $\mathrm{ZZ}$ reservoir demonstrated its lowest concentration in the sediments of the middle part of the reservoir (transect $\mathrm{C}$ ) and in small areas of the north-western and south-eastern parts (Fig. 4a). The greatest $\mathrm{Pb}$ accumulation was established in the sediments from the backwater reservoir. Also, relatively high $\mathrm{Pb}$ concentration in the sediments of the north-eastern part (bay) of the reservoir should be highlighted.

Lead concentration in the sediments of the first part of the BI reservoir (average $48.5 \mathrm{mg}^{\mathrm{kg}} \mathrm{k}^{-1}$ ) (Tab. 4) was close to this element level in the $\mathrm{ZZ}$ sediments. Importantly, in the undredged part, it was much higher and averaged $107.1 \mathrm{mg} \cdot \mathrm{kg}^{-1}$. The differences of the mean $\mathrm{Pb}$ concentrations between the sediments of transect VII of this part and the sediments of transect IV and V proved to be statistically significant.

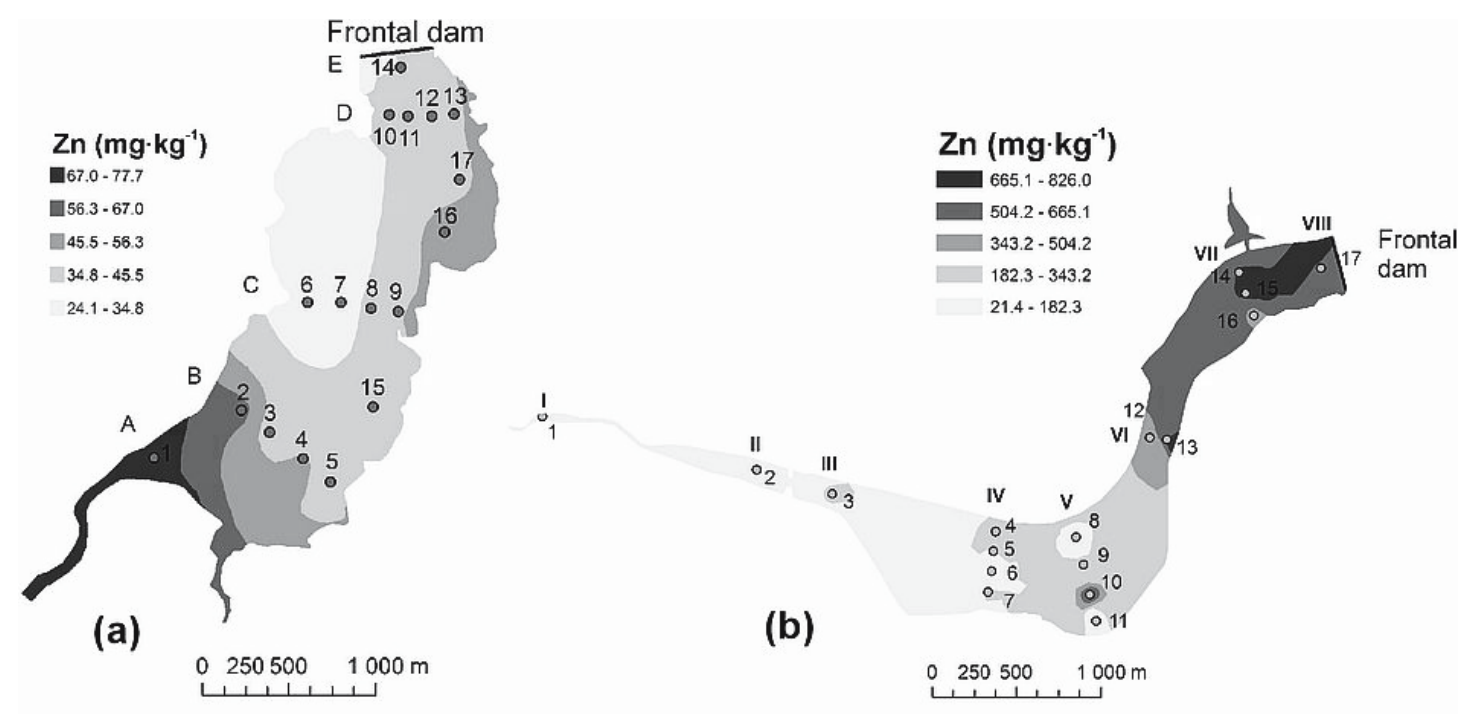

Fig. 3. Spatial distribution of Zn in bottom sediments of the reservoirs: Zalew Zemborzycki (a) and Brody lłżeckie (b) 


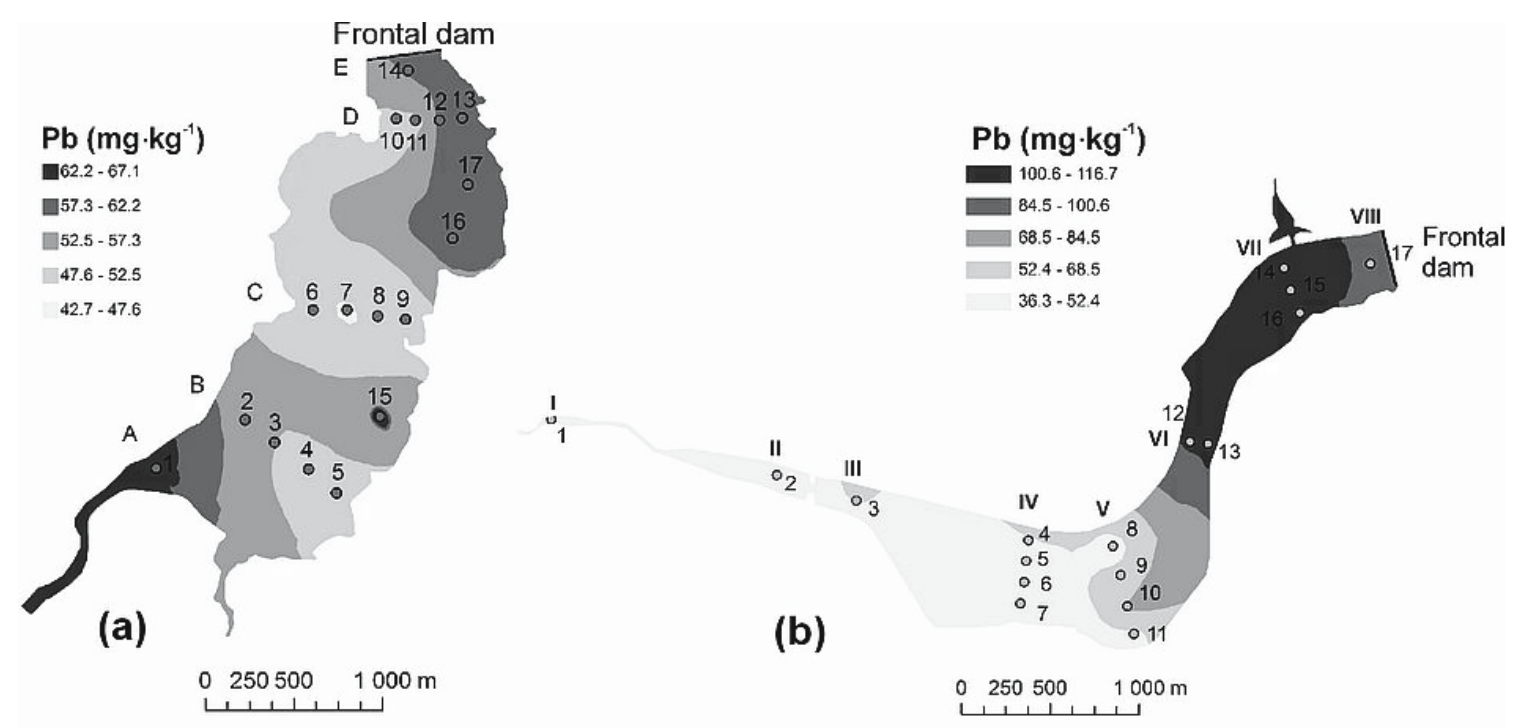

Fig. 4. Spatial distribution of $\mathrm{Pb}$ in bottom sediments of the reservoirs: Zalew Zemborzycki (a) and Brody lłżeckie (b)

The distribution of $\mathrm{Pb}$ concentration in the sediments of the Brody Iłżeckie reservoir showed that eight samples were in the lowest range $\left(36.3-52.4 \mathrm{mg} \mathrm{kg}^{-1}\right)$, whereas five samples were in the highest $\left(100.6-116.7 \mathrm{mg}^{-1} \mathrm{~kg}^{-1}\right)$. No samples in the medium $\mathrm{Pb}$ content range were found (Fig. 4b).

The spatial distribution map of $\mathrm{Pb}$ concentration in sediments (Fig. 4b) in the first (dredged) part and the second (undredged) part of the BI reservoir displays clear similarity to the $\mathrm{Mn}$ and $\mathrm{Zn}$ distribution in the sediments of this dam reservoir.

\section{Cadmium}

Overall mean concentration of $\mathrm{Cd}$ in sediments of the $\mathrm{ZZ}$ reservoir was at the level of $0.50 \mathrm{mg}^{-1}$ (Tab. 3). In the sediments of transect $\mathrm{C}$, on average, less $\mathrm{Cd}$ was determined in comparison to transect A, B and D. In the sediments of last three transects, mean $\mathrm{Cd}$ concentrations were similar.

Most of the sediment samples $(n=6)$ had $\mathrm{Cd}$ concentration within the medium $\left(0.44-0.54 \mathrm{mg} \cdot \mathrm{kg}^{-1}\right)$ and the higher ranges, i.e. $0.54-0.65 \mathrm{mg}^{-1} \mathrm{~kg}^{-1}(\mathrm{n}=5)$ (Fig. 5a). The lowest and highest intervals contained two samples each. The distribution is slightly skewed to the left $(\mathrm{As}=-0.6)$.

The Cd spatial distribution in sediments of the $\mathrm{ZZ}$ reservoir, below the transect $B$, showed a marked longitudinal zonation (perpendicular to the frontal dam) (Fig. 5a). The $\mathrm{Cd}$ concentration in the sediments of this part increased from the western bank towards the east.

In the sediments of the $\mathrm{BI}$ reservoir, $\mathrm{Cd}$ concentration varied greatly (Tab. 4, Fig. 5b). In the undredged part, the range and cadmium mean values were several-fold higher compared to sediments in the dredged part. The differences between the mean values for transect VII of the undredged part and those for IV and V of the dredged part were statistically significant.

Most of the sediment samples collected from the BI reservoir were found to be within the two lowest intervals of Cd concentrations, i.e. $0.31-1.52(\mathrm{n}=5)$ and $1.52-2.73 \mathrm{mg} \mathrm{kg}^{-1}$ $(n=7)$ (Fig. 5b). However, the highest concentration of this element was established in three samples. This is a rightskewed distribution $(\mathrm{As}=0.8)$.
Overall mean concentration of cadmium in sediments of the BI reservoir was shown to be ca. 5 times higher than its mean concentration in the $\mathrm{ZZ}$ sediments.

Cadmium spatial distribution in sediments of the BI reservoir resembled that of $\mathrm{Mn}$ and $\mathrm{Zn}$ distribution (Fig. 5b). Its concentration heightened towards the frontal dam. Similarly, the sediments from sampling locations VII16 and VIII17 had a far smaller amount of $\mathrm{Cd}$ than did other points in this part of the reservoir.

\section{Copper}

The greatest concentrations of $\mathrm{Cu}$ in sediments of the $\mathrm{ZZ}$ reservoir were reported in the sediments of the upper part of the reservoir, i.e. point A1 and sediments of transect B (Tab. 3, Fig. 6a). The lowest mean concentration was established in sediments of transect $\mathrm{C}\left(5.0 \mathrm{mg} \mathrm{kg}^{-1}\right)$, and intermediate equal to overall mean in the sediments of transect $\mathrm{D}$ (Tab. 3). The differences between the mean values for transect $\mathrm{B}$ and $\mathrm{C}$ were statistically significant.

Most of the ZZ sediment samples under investigation ranged within the medium $\left(5.7-7.1 \mathrm{mgkg}^{-1}, \mathrm{n}=6\right)$ and higher (7.1-8.4 $\mathrm{mg}^{-1} \mathrm{~kg}^{-1}, \mathrm{n}=6$ ) intervals of $\mathrm{Cu}$ values. However, only one sample was found in the lowest and three in the highest copper concentration interval (Fig. 6a). This is a left-skewed distribution (As $=-0.7)$.

Copper spatial distribution in sediments of the $\mathrm{ZZ}$ reservoir was similar to cadmium distribution. In the area below transect $\mathrm{B}$, longitudinal zonation (perpendicular to the frontal dam) was noted, and element content increased from the left bank towards the right bank of the reservoir (Fig. 6a).

In sediments of the $\mathrm{BI}$ reservoir, $\mathrm{Cu}$ concentration ranged within a broad interval (Tab. 4, Fig. 6b). Similar to the elements already estimated, copper concentration in sediments of the initial part (I-III) and dredged part (IV-V) was markedly lower (on average ca. 4.6 and 3.9 times, respectively) compared to the undredged part. The differences between the means of transect IV and VII were statistically significant.

$\mathrm{Cu}$ concentration in nine sediment samples taken from the BI reservoir was reported to be within the lowest interval (1.3-10.6 $\left.\mathrm{mgkg}^{-1}\right)$, whereas the other eight samples were 


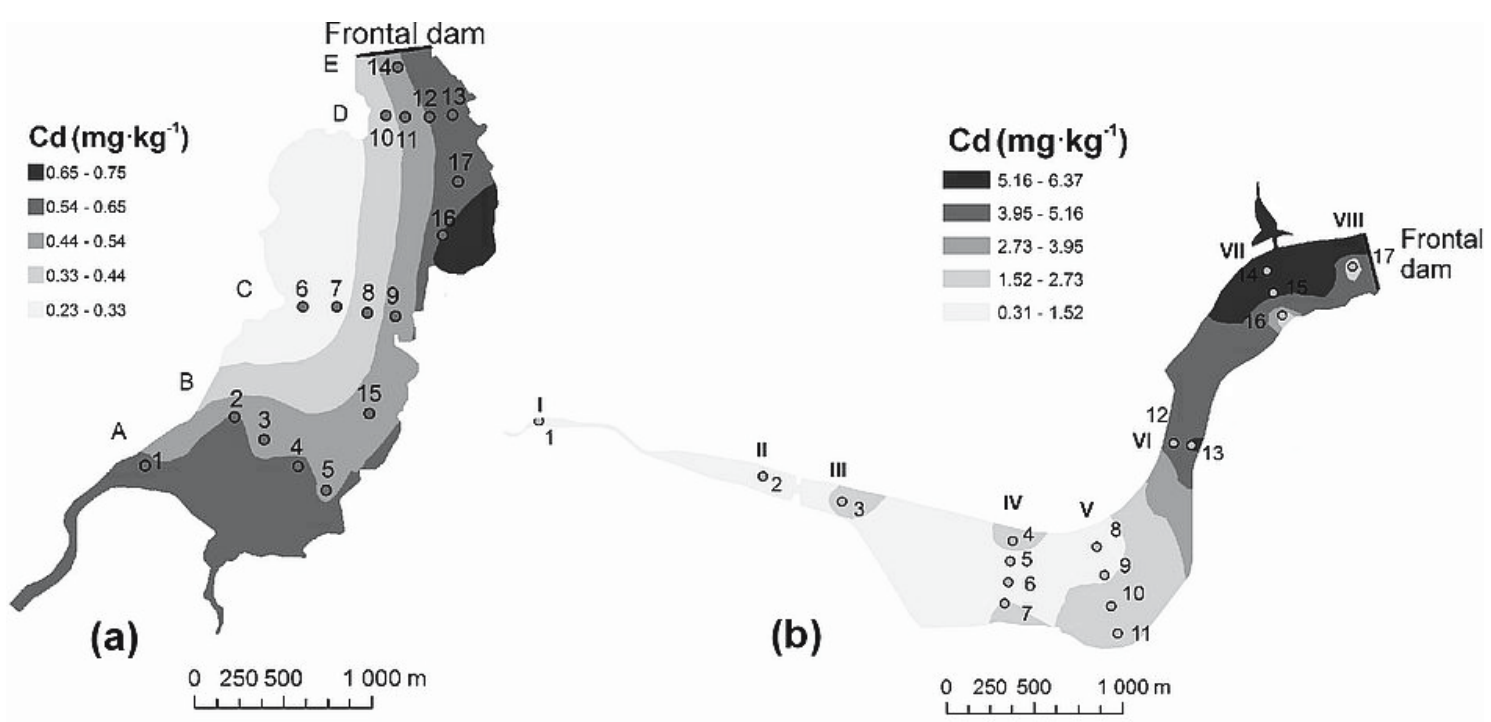

Fig. 5. Spatial distribution of Cd in bottom sediments of the reservoirs: Zalew Zemborzycki (a) and Brody lłżeckie (b)

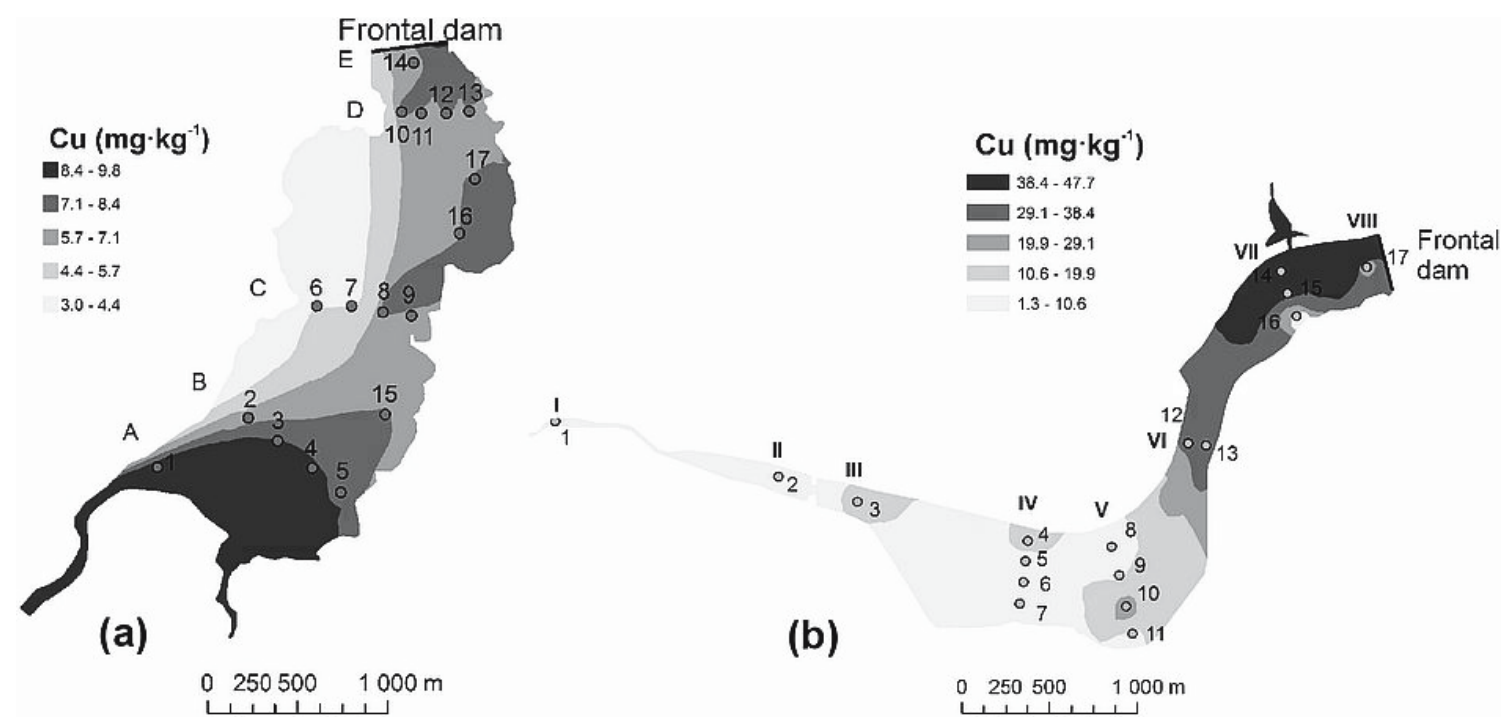

Fig. 6. Spatial distribution of $\mathrm{Cu}$ in bottom sediments of the reservoirs: Zalew Zemborzycki (a) and Brody lłżeckie (b)

found within four higher intervals, two samples each (Fig. 6b). This is a right-skewed distribution $(\mathrm{As}=0.9)$. Mean total $\mathrm{Cu}$ concentration in sediments of the BI reservoir $\left(16.6 \mathrm{mg} \mathrm{kg}^{-1}\right)$ was 2.3 times higher than the mean in sediments of the $\mathrm{ZZ}$.

The $\mathrm{Cu}$ spatial distribution in the BI reservoir displayed the same pattern as that of other discussed elements, i.e. $\mathrm{Cu}$ level increased in sediments closer to the frontal dam, and was lower in the sediments of locations VII16 and VIII17 than in the sediments of neighbouring locations VII14 and VII15 (Fig. 6b).

\section{Chromium}

Mean total chromium concentration in sediments of Zalew Zemborzycki reached $5.9 \mathrm{mg} \cdot \mathrm{kg}^{-1}$ at a very wide interval $\left(0.1-14.1 \mathrm{mg} \mathrm{kg}^{-1}\right)$ and a high variation coefficient $(66.9 \%)$ (Tab. 3). The greatest differentiation and the lowest mean $\mathrm{Cr}$ content $\left(3.9 \mathrm{mg} \mathrm{kg}^{-1}\right)$ were established in the sediments of transect $\mathrm{C}$, with the lowest differentiation and the highest mean $\left(8.3 \mathrm{mg} \cdot \mathrm{kg}^{-1}\right)$ in sediments of transect B in the upper part of the reservoir. The intermediate values were stated in the sediments of sector $\mathrm{D}$, in the lower part of the reservoir. The differences between the mean $\mathrm{Cr}$ values in sediments of these transects were not statistically significant.

The number of sediment samples in each $\mathrm{Cr}$ concentration interval was evenly distributed, three or four samples in a given interval (Fig. 7a).

The chromium spatial distribution in sediments of $\mathrm{ZZ}$ displays a regularity similar to the $\mathrm{Cd}$ and $\mathrm{Cu}$ distribution. The regularity consists of the occurrence of the highest values zone in sediments of the upper and north-eastern parts of the reservoir (Fig. 7a). Cr concentration in sediments below transect B was shown to be arranged in the zones perpendicular to the frontal dam.

In sediments of the $\mathrm{BI}$ reservoir, $\mathrm{Cr}$ concentration was even more differentiated than in sediments of ZZ (Tab. 4, Fig. 7b). Mean concentration in sediments of the first part (I-V) was at $18.51 \mathrm{mg} \cdot \mathrm{kg}^{-1}$. In sediments of the second part (undredged), it was 4.5 -fold higher and reached $83.4 \mathrm{mg} \cdot \mathrm{kg}^{-1}$. 


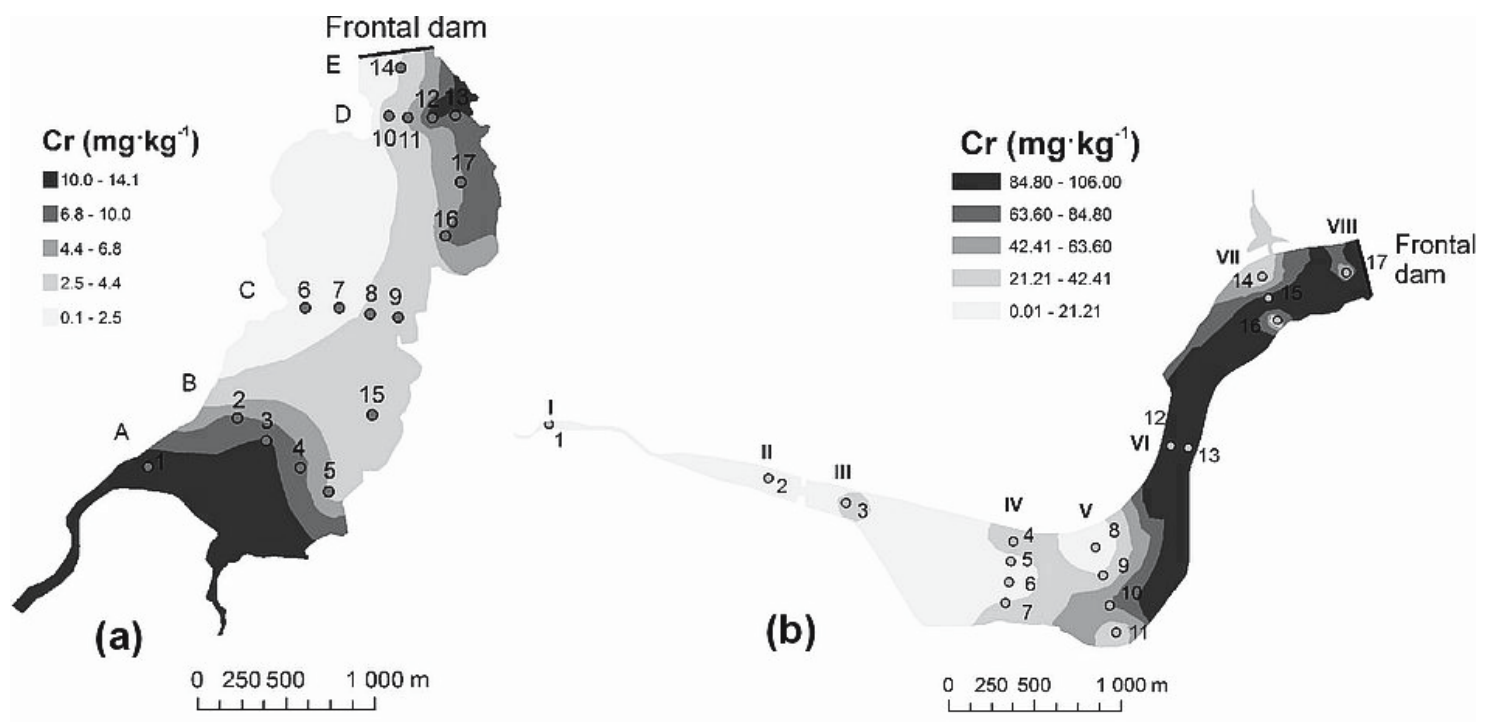

Fig. 7. Spatial distribution of $\mathrm{Cr}$ in bottom sediments of the reservoirs: Zalew Zemborzycki (a) and Brody ltżeckie (b)

The differences between $\mathrm{Cr}$ mean content in sediments of transects IV, V and VII were statistically significant.

In sediments of the Brody Iłżeckie reservoir, overall mean $\mathrm{Cr}$ content was found to be 7 times, and in the undredged part ca. 14 times higher, as compared to the overall mean of $\mathrm{Cr}$ content in sediments of $\mathrm{ZZ}$.

Sediment sample distribution in each interval of $\mathrm{Cr}$ content was highest $(\mathrm{n}=8)$ in the range $0.01-21.21 \mathrm{mgkg}^{-1}$ and lowest $(\mathrm{n}=4)$ in the interval $21.21-42.41 \mathrm{mgkg}^{-1}$ (Fig. $\left.7 \mathrm{~b}\right)$. The interval of the highest values contained three samples, while no samples were reported in the interval $63.60-84.80 \mathrm{mg} \mathrm{kg}^{-1}$. This is a right-skewed distribution $(\mathrm{As}=1.0)$.

Spatial distribution of $\mathrm{Cr}$ accumulation in sediment of the BI reservoir demonstrated similarity to the distribution of the elements already discussed (Fig. 7b). Cr concentration was the lowest in the reservoir backwater area, increasing towards the frontal dam. In the lower part of the reservoir, the area of the locations VII14, VII16 and VIII17 was distinguished because of a lower $\mathrm{Cr}$ amount in the samples collected there as compared to sediment samples from the other sites in this part.

\section{Nickel}

$\mathrm{Ni}$ concentration in sediments of $\mathrm{ZZ}$ oscillated between $1.4 \mathrm{mg} \mathrm{kg}^{-1}$ and $9.5 \mathrm{mg} \cdot \mathrm{kg}^{-1}$ (Tab. 3, Fig. 8a). Mean concentration in sediments of sector $\mathrm{C}$ in the middle part of the reservoir was far lower in comparison to transects B and D, but not statistically significant. The overall mean value was close to the median.

Most sediment samples were found in the medium interval of $\mathrm{Ni}$ concentrations, i.e. $4.6-6.3 \mathrm{mgkg}^{-1}(\mathrm{n}=7)$, in the higher $(n=5)$ and in the highest interval $(n=3)$ (Fig. 8a). Only two samples were below the medium range. It is a distribution approaching the normal one (As $=-0.2)$.

The Ni spatial distribution in the ZZ sediments was similar to the distribution of $\mathrm{Cu}, \mathrm{Cd}$ and $\mathrm{Cr}$ (Fig. 8a). The highest concentrations zone occurred in the upper part of the reservoir and the north-eastern area of the lower part, while in between them the sediments with lower Ni concentrations were reported. In this zone, $\mathrm{Ni}$ concentration increased from the left bank towards the right one.
In sediments of $\mathrm{BI}$, like $\mathrm{Cr}$, $\mathrm{Ni}$ concentration was strongly differentiated and ranged between 0.01 and $55.4 \mathrm{mgkg}^{-1}$ (Tab. 4, Fig. 8b). In the second part of the reservoir (VI-VIII), mean Ni concentration was ca. 5.4 times higher than in the first part (I-V). The differences between the mean concentration in sediments of transects IV and VII were statistically significant.

Overall mean concentration of $\mathrm{Ni}$ in sediments of $\mathrm{BI}$ was 2.3 times higher - and 4.9 fold higher in the undredged part - than in sediments of ZZ.

Most samples $(n=10)$ of sediments from the BI reservoir were within the lowest $\mathrm{Ni}$ accumulation values, that is from 0.01 to $11.09 \mathrm{mg} \cdot \mathrm{kg}^{-1}$ (Fig. 8b). There were three samples in higher ranges, while the intervals under the medium and the highest values contained only one sample each.

The nickel spatial distribution in sediments of BI indicates a zonal pattern of its concentration parallel to the dam. This arrangement changes a little in the area below transect VI, taking a skewed direction to the dam.

In the $\mathrm{ZZ}$ reservoir, the metals in sediments, by overall mean values in $\mathrm{mgkg}^{-1}$, followed the order: $\mathrm{Mn}>\mathrm{Pb}>\mathrm{Zn}>\mathrm{Cu}>\mathrm{Ni}>$ $\mathrm{Cr}>\mathrm{Cd}$. In the BI reservoir, the order was slightly different, yet the same according to mean content for the first (I-V) and second (VI-VIII) parts, as well as according to the overall mean for the reservoir: $\mathrm{Mn}>\mathrm{Zn}>\mathrm{Pb}>\mathrm{Cr}>\mathrm{Cu}>\mathrm{Ni}>\mathrm{Cd}$.

\section{Evaluation of heavy metal concentration in sediments}

Sediments were evaluated according to the geochemical and ecotoxicological criteria (Tab. 5). In the sediments of ZZ, overall mean concentrations of the analyzed heavy metals according to the geochemical criterion, in the case of zinc and chromium, were at the level of geochemical background, while cadmium exceeded the background minimally (class I), and copper and nickel were within class I. In the matter of lead, the mean concentration was in class II, i.e. moderately polluted sediments.

The concentration of all heavy metals in sediments of the BI reservoir was lower on average in the dredged part than in the undredged one. In the first part, mean concentration of 


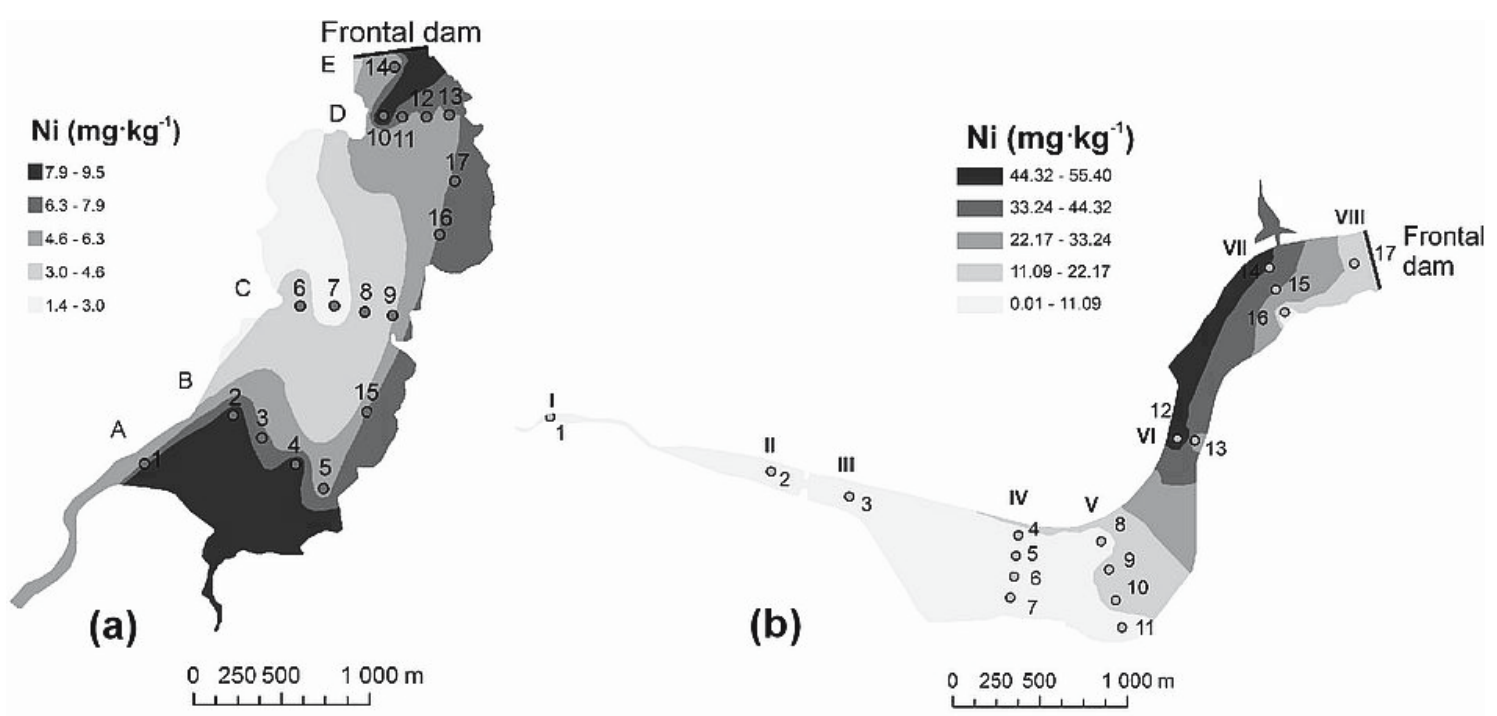

Fig. 8. Spatial distribution of Ni in bottom sediments of the reservoirs: Zalew Zemborzycki (a) and Brody lłżeckie (b)

Table 5. Evaluation of heavy metals concentration in the sediments of the reservoirs by mean values

\begin{tabular}{|c|c|c|c|c|c|}
\hline Element & Class $^{a}$ & $\mathrm{TEL}^{\mathrm{b}}$ & $\mathrm{PEL}^{\mathrm{b}}$ & TEC $^{\mathrm{c}}$ & $\mathrm{PEC}^{\mathrm{c}}$ \\
\hline \multicolumn{6}{|c|}{ Zalew Zemborzycki } \\
\hline $\mathrm{Zn}$ & $\mathrm{GB}^{\mathrm{d}}$ & $-{ }^{\mathrm{e}}$ & - & - & - \\
\hline $\mathrm{Pb}$ & II & $++^{e}$ & - & + & - \\
\hline $\mathrm{Cd}$ & I & - & - & - & - \\
\hline $\mathrm{Cu}$ & 1 & - & - & - & - \\
\hline $\mathrm{Cr}$ & GB & - & - & - & - \\
\hline $\mathrm{Ni}$ & 1 & - & - & - & - \\
\hline \multicolumn{6}{|c|}{ Brody lłżeckie } \\
\hline \multicolumn{6}{|c|}{ The inflow and dredged part $(\mathrm{I}-\mathrm{V})$} \\
\hline Zn & $\mathrm{I}$ & + & - & + & - \\
\hline $\mathrm{Pb}$ & II & + & - & + & - \\
\hline $\mathrm{Cd}$ & II & + & - & + & - \\
\hline $\mathrm{Cu}$ & 1 & - & - & - & - \\
\hline $\mathrm{Cr}$ & 1 & - & - & - & - \\
\hline $\mathrm{Ni}$ & GB & - & - & - & - \\
\hline \multicolumn{6}{|c|}{ Undredged part (VI-VIII) } \\
\hline $\mathrm{Zn}$ & III & + & + & + & + \\
\hline $\mathrm{Pb}$ & III & + & + & + & - \\
\hline $\mathrm{Cd}$ & III & + & + & + & - \\
\hline $\mathrm{Cu}$ & 1 & - & - & + & - \\
\hline $\mathrm{Cr}$ & II & + & - & + & - \\
\hline $\mathrm{Ni}$ & II & + & - & + & - \\
\hline \multicolumn{6}{|c|}{ All sediments (I-VIII) } \\
\hline $\mathrm{Zn}$ & II & + & + & + & - \\
\hline $\mathrm{Pb}$ & II & + & - & + & - \\
\hline $\mathrm{Cd}$ & II & + & - & + & - \\
\hline $\mathrm{Cu}$ & 1 & - & - & - & - \\
\hline $\mathrm{Cr}$ & 1 & + & - & - & - \\
\hline $\mathrm{Ni}$ & 1 & - & - & - & - \\
\hline
\end{tabular}

${ }^{a}$ geochemical criteria (Bojakowska and Sokołowska 1998), ${ }^{\mathrm{b}}$ ecotoxicological criteria (Smith et. al. 1996 after MacDonald et al. 2000), ${ }^{\mathrm{c}}$ ecotoxicological criteria (MacDonald et al. (2000), ${ }^{d} \mathrm{~GB}-$ geochemical background, ${ }^{e}(+)$ threshold value exceeded, $(-)$ below the threshold value 
$\mathrm{Zn}, \mathrm{Cu}$ and $\mathrm{Cr}$ was found within the class I interval; lead and cadmium were found in class II, and nickel in the geochemical background range (Tab. 5). According to the geochemical evaluation, sediments in the undredged part were polluted (class III) in terms of $\mathrm{Zn}, \mathrm{Pb}, \mathrm{Cd}$ concentration, moderately polluted (class II) with respect to $\mathrm{Cr}$ and $\mathrm{Ni}$, and only slightly polluted (class I) with $\mathrm{Cu}$. Then again, evaluating the sediments of this reservoir as per the overall mean, it was stated that $\mathrm{Zn}$, $\mathrm{Pb}, \mathrm{Cd}$ concentrations were maintained at the class II level, with other elements at class I.

Bottom sediments of $\mathrm{ZZ}$ showed the average concentration of the analyzed heavy metals at a level under TEL (Smith et. al. 1996 after MacDonald et al. 2000), and TEC (MacDonald et al. 2000) values (Tab. 5), with the exception of lead, whose sedimentary average concentration exceeded the aforementioned guideline values. That only indicates that $\mathrm{Pb}$ may have potentially adverse, though rarely observed, effect on aquatic organisms.

The quality of sediments from the BI reservoir with regard to heavy metal concentration was differentiated depending on the reservoir part. Therefore, like the geochemical assessment, the ecotoxicological evaluation was conducted for three kinds of mean values (Tab. 5). For zinc, cadmium and lead, the mean concentration in the part from sampling location I1 to transect V was found to surpass the TEL and TEC boundary values, but no metal concentration exceeded the PEL and PEC second threshold values. However, in the undredged part, concentrations of all the analyzed metals were determined above the TEL and TEC values (except for $\mathrm{Cu}-\mathrm{TEL}$ ). It is noteworthy that $\mathrm{Zn}, \mathrm{Pb}$ and $\mathrm{Cd}$ values also surpassed the PEL values, while in the case of zinc, the PEC values as well. The overall mean of the analyzed metals in the sediments of the BI reservoir has exceeded the PEL value in the case of zinc.

\section{Discussion}

The research results demonstrated the differences between the reservoirs in terms of heavy metal concentration in sediments and their spatial distribution patterns. The analysed metal concentration in sediments of BI was found to be several times higher than that of ZZ. The highest differences, according to overall mean value, were established for $\mathrm{Zn}$ and $\mathrm{Cr}$ (8- and 7-fold, respectively), then for Cd and Mn (4.9- and 4.3-fold, respectively) and for $\mathrm{Cu}, \mathrm{Ni}, \mathrm{Pb}$ (2.3-, 2.3- and 1.3-fold, respectively). It is notable that the differences were even greater (ca. twice) when comparing the heavy metal mean concentrations in sediments from the undredged part of BI and the overall mean of $\mathrm{ZZ}$. Besides, the maximum concentrations of $\mathrm{Zn}, \mathrm{Ni}, \mathrm{Cd}, \mathrm{Mn}, \mathrm{Cr}, \mathrm{Cu}, \mathrm{Pb}$ in sediments of the $\mathrm{BI}$ reservoir were 10.6, 9.1, 8.5, 7.6, 7.5, 4.9, 1.7 times higher, respectively, than the maximum concentration values in the sediments of the $\mathrm{ZZ}$ reservoir.

The studies indicated spatial differentiation of the heavy metal concentrations in sediments of both reservoirs. In sediments of $\mathrm{ZZ}$, the lowest mean concentrations were established in the transect $\mathrm{C}$ sediments. This was likely a result of the reservoir narrowing in this area, where the water flow is faster and, consequently, coarse grained particles settle out and undergo sedimentation. It is also reflected in the texture of sediments, i.e. a higher percentage of coarse fractions and a lower percentage of fine fractions, as has been indicated in earlier studies (Ligęza and Smal 2002). Such conditions do not favor fine fraction or organic matter deposition (Smal et al. 2013), which are vital in metal sorption and hence in metal accumulation in sediments (Korfali et al. 2006).

The spatial distribution of the analyzed metals in sediments of $\mathrm{ZZ}$ indicated two zones where accumulation of metal was greatest: the upper part of the reservoir and the lower part towards the frontal dam, especially the north-eastern bay area. In the first case, a higher metal concentration arises from external loads from the Bystrzyca River, while in the second, accumulation of metal is due to its sedimentation together with clay and silt particles. Higher levels of $\mathrm{Zn}, \mathrm{Cu}$ and $\mathrm{Pb}$ in the backwater area were also reported by Korfali et al. (2006), who attribute it to sewage inflow and the industrial contaminants from the Litani River valley.

Another characteristic of sediments from $\mathrm{ZZ}$ is that their heavy metal concentration elevates from the left bank (western) in a rightward (eastern) direction. A similar distribution pattern was determined for nitrogen and phosphorus (Smal et al. 2013), and organic carbon (Smal et al. 2015). Thus, metals distribution may be explained in much the same way. One of the reasons may be a difference in hydrodynamic conditions of each reservoir part. The upper part, and partially the left bank, are riverine in character, as the parent river flows closer to the left bank and away from the right one (Misztal and Smal 1980). Generally, riverine zones of a reservoir are shallow and characterized by a high water flow rate (Thornton et al. 1996). Organic and mineral particles are transported by advective currents but a small part of them is sedimented. Low metal concentration in the left-bank sediments may be caused by lower depth and higher water dynamics as compared to the right-bank one. Another reason for this may be linked to a relatively high water waving rate in this area, which is unsheltered from prevailing western winds. Wind-driven turbulence causes moving suspension and resuspended sediments (Sarà 2009). Unlike the left-bank part, the right-bank part, especially the bay sites, south-eastern and north-eastern areas are at the greatest distance from the river current.

The spatial distribution of heavy metal concentrations in sediments of Brody Iłżeckie indicates their lower levels in the area by the frontal dam, as compared with other sediments in the second part of the reservoir. This is unquestionably a consequence of the lower outflow system in this reservoir. Such a system contributes to more effective sediment transport and outflow from the frontal dam area, mainly fine mineral fractions and organic matter together with adsorbed metals (Smal et al. 2013).

In sediments of Zalew Zemborzycki, the concentrations of the analyzed metals were either recorded at the geochemical background level ( $\mathrm{Zn}$ and $\mathrm{Cr}$ ) or they showed slight contamination, so they do not pose any threat for aquatic organisms. Only the $\mathrm{Pb}$ concentration detected exceeded the TEL and TEC values, whereas regarding the geochemical criterion, sediments from the undredged part of Brody Iłżeckie were contaminated in terms of $\mathrm{Zn}, \mathrm{Pb}$ and $\mathrm{Cd}$ concentration. These concentrations surpassed the PEL values, while $\mathrm{Zn}$ surpassed the PEC values as well. Thus, these metals present a danger to aquatic organisms.

Large amounts of heavy metals in sediments of BI give evidence of their anthropogenic origin (Loska and Wiechuła 2003). Anthropogenic sources include industrial wastewater, chiefly generated by the metallurgical industry and 
discharged into the Kamienna River for some decades. A much lower heavy metal concentration was found in sediments of the dredged part, which affirms an appreciably slower sediment accumulation rate throughout the last two decades, as compared to the previous ones after the reservoir became operational. It may imply diminished loads of metals with industrial sewage, which in turn may be associated with two factors. The first one is decreased industrial production and hence, decreased generation of sewage in the face of economic crisis and political-economic transformation in Poland in the 1990s, while the second factor is the better overall efficiency of wastewater treatment. Also, as mentioned previously, the role of the traditional industrial branches of this region has been reduced in favor of small and medium-sized businesses.

Mean concentrations of $\mathrm{Cr}$ and $\mathrm{Pb}$ in sediments of $\mathrm{ZZ}$ were comparable, while those of $\mathrm{Cd}$ and $\mathrm{Zn}$ were lower than ten years ago (Ligęza et al. 2004). The levels of all the analyzed metals in sediments of $\mathrm{ZZ}$ were considerably lower than the data (mean values) reported by Gierszewski (2008) for the sediments of the Włocławski reservoir on the Vistula River. Moreover, when compared to the concentrations in sediments of the Kozłowa Góra reservoir on the Brynica River (Rosińska and Dąbrowska 2011), the ZZ analyzed metal levels were comparable for $\mathrm{Cu}, \mathrm{Ni}, \mathrm{Cr}$, but lower for $\mathrm{Cd}$ and $\mathrm{Pb}$. As for $\mathrm{Cr}$ concentration they were also comparable with sediments of the Goczałkowice reservoir (Jabłońska et al. 2012), but lower than in sediments of the Pławniowice reservoir (Jabłońska-Czapla et al. 2014). In the ZZ sediments, the concentration of all the investigated metals except lead were lower than those established in sediments of the Emigrant Creek Dam in Australia (Akhurst et al. 2012), the Kowsar Dam in Iran (Karbassi et al. 2011) and the Manwan Reservoir in China (Zhao et al. 2013). Lastly, apart from $\mathrm{Pb}$ and $\mathrm{Cd}$, the concentrations in $\mathrm{ZZ}$ sediments were lower than those determined in sediments of the Beyler reservoir in Turkey (Findik and Turan 2012).

Though the concentration levels of the analyzed metals in sediments of Brody Iłżeckie were several-fold higher than those in Zalew Zemborzycki, they were still greatly lower than the metal concentration levels in sediments of the Rybnik reservoir, located in the industrial region of the Upper Silesia (southern Poland), as observed by Loska and Wiechuła (2003), and by Kostecki and Kowalski (2007). The first authors report that the mean concentration of copper in the studied sediments reached 451.7, cadmium 25.8, zinc 1583.4, and nickel $71.1 \mu \mathrm{g}^{-1}$. Thus, the mean concentration in sediments from the undredged part of BI was 14.2, 5.6, 2.5 and 2.4 times lower, respectively, as compared to the above mentioned values. It was also lower (except for $\mathrm{Pb}$ and $\mathrm{Zn}$ ) than in sediments from the Włocławski reservoir (Gierszewski 2008). The metal concentration in the undredged part of BI, though, was higher than in the Beyler reservoir sediments (Findik and Turan 2012), higher (except for $\mathrm{Cu}$ and $\mathrm{Ni}$ ) as compared to the Manwan Reservoir (Zhao et al. 2013) and higher (except for chromium) as compared to the Seyhan reservoir in Turkey (Çevik et al. 2009). In the last one, the high $\mathrm{Cr}$ concentration was related to chromium ore deposits in this region.

\section{Conclusions}

Differences were found between the reservoirs in terms of heavy metal concentrations in bottom sediments. In the $\mathrm{ZZ}$ sediments they were low and according to the geochemical criterion at the level of: geochemical background $(\mathrm{Zn}, \mathrm{Cr}$ ), slightly contaminated sediments $(\mathrm{Cd}, \mathrm{Cu}, \mathrm{Ni})$ and moderately contaminated sediments $(\mathrm{Pb})$. In sediments of $\mathrm{BI}$, metal concentrations were several times higher than in sediments of $\mathrm{ZZ}$. The greatest differences, according to the overall mean value, were determined for $\mathrm{Zn}$ and $\mathrm{Cr}$, then for $\mathrm{Cd}$ and $\mathrm{Mn}$ and, finally, for $\mathrm{Cu}, \mathrm{Ni}$ and $\mathrm{Pb}$. The differences were even higher when the metal mean values in sediments of the undredged part of BI were compared to the overall mean of the $\mathrm{ZZ}$ reservoir. Sediments of the undredged part of BI were evaluated as contaminated in relation to $\mathrm{Zn}, \mathrm{Pb}$ and $\mathrm{Cd}$ concentration, moderately contaminated in relation to $\mathrm{Cr}$ and $\mathrm{Ni}$ and slightly contaminated in relation to $\mathrm{Cu}$. The metals originated from anthropogenic sources, i.e. industrial sewage, mainly from the metallurgical and metal industries. Evaluation of sediment quality according to the ecotoxicological criteria showed a threat to aquatic organisms of the Brody Iłżeckie reservoir, caused primarily by $\mathrm{Zn}, \mathrm{Pb}$ and $\mathrm{Cd}$ content exceeding the PEL values.

Great differentiation of heavy metal concentrations in the studied sediments was observed (depending on the sampling site) and regularities in their spatial distribution pattern. In ZZ, sediments of transect $C$ (reservoir narrowing) had on average the lowest concentration of metals as compared to other transects. The highest concentration of metals was established in the upper part of the reservoir, which proves their external loads from the Bystrzyca River. Relatively high metal contents were also determined in the lower part, especially the bay part of the reservoir, which results from the sedimentation process of the metal along with silt and clay particles.

Sediments of the Brody Iłżeckie reservoir displayed more varied concentrations than those of Zalew Zemborzycki, which is attributed to the dredging treatment performed in the majority of the reservoir. The concentration of the studied metals in the dredged part was several times lower than in the undredged one. This provides evidence that over the last decades, after the dredging operation, accumulation of these metals was slight.

The research results indicate that in small and shallow reservoirs, spatial distribution (accumulation) of heavy metals depends on such factors as a parent river current, reservoir depth, water waving, reservoir shape (narrowing, coves/bays), and type of outflow.

\section{Acknowledgments}

The studies were performed within a project financed by the Ministry of Science and Higher Education: No. N N305 410238.

\section{References}

Akhurst, D.J., Clark, M.W., Reichelt-Brushett, J. \& Jones, G.B. (2012). Elemental speciation and distribution in sediments of a eutrophied subtropical freshwater reservoir using postextraction normalization, Water Air and Soil Pollution, 223, pp. 4589-4604.

Aleksander-Kwaterczuk, U. \& Helios-Rybicka, E. (2009). Contaminated sediments as a potential source of $\mathrm{Zn}, \mathrm{Pb}$, and $\mathrm{Cd}$ for a river system in the historical metalliferous ore mining and smelting industry area of South Poland, Journal of Soils and Sediments, 9, pp. 13-22. 
Arnason, J.G. \& Fletcher, B.A. (2003). A 40+ year record of Cd, Hg, $\mathrm{Pb}$, and $\mathrm{U}$ deposition in sediments of Patroon Reservoir, Albany County, NY, USA, Environmental Pollution, 123, pp. 383-391.

Bojakowska, I. \& Gliwicz, T. (2005). Chlorinated pesticides and polychlorinated biphenyls in river sediments of Poland, Przeglad Geologiczny, 53, pp. 649-655. (in Polish)

Bojakowska, I. \& Sokołowska, G. (1998). Geochemical classes of water sediments quality, Przeglad Geologiczny, 46, pp. 49-54. (in Polish)

Campbell, J.A., Whitelaw, K., Riley, J.P., Head, P.C. \& Jones, P.D. (1988). Contrasting behaviour of dissolved and particulate nickel and zinc in a polluted estuary, Science of the Total Environment, 71, pp. 141-155.

Çevik, F., Göksu, M.Z.L., Derici, O.B. \& Findik, Ö. (2009). An assessment of metal pollution in surface sediments of Seyhan dam by using enrichment factor, geoaccumulation index and statistical analyses, Evironmental Monitoring and Assessment, 152, pp. 309-317.

Ciszewski, D., Kubsik, U. \& Aleksander-Kwaterczuk, U. (2012). Long-term dispersal of heavy metals in a catchment affected by historic lead and zinc mining, Journal of Soils and Sediments, 12, pp. 1445-1462.

Dang, T.C. \& Jeffrey, P.O. (2006). Metal speciation in coastal marine from Singapore using a modified BCR sequential extraction procedure, Applied Geochemistry, 21, pp. 1335-1346.

Darmody, R.G. \& Marlin, J.C. (2002). Sediments and sediment-derived soils in Illinois: pedological and agronomic assessment, Environmental Monitoring and Assessment, 77, pp. 209-227.

Demirak, A., Yilmaz, F., Tuna, A.L., Tuna, A.L. \& Ozdemir, N. (2006). Heavy metals in water, sediment and tissues of Leuciscus cephalus from a stream in southwestern Turkey, Chemosphere, 63, pp. 1451-1458.

Dmitruk, U., Jancewicz, A. \& Tomczuk, U. (2013). Hazardous organic and trace element occurrence in bottom sediments of dam reservoirs, Ochrona Środowiska, 3, pp. 63-68. (in Polish)

Findik, Ö. \& Turan, M.A. (2012). Metal concentrations in surface sediments of Beyler reservoir (Turkey), Bulletin of Environmental Contamination and Toxicology, 88, pp. 193-197.

Gierszewski, P. (2008). Concentration of heavy metals in sediments of Włocławski reservoir as an index for hydrodynamic conditions of deposition, Landform Analyses, 9, pp. 79-82. (in Polish)

Hu, B., Li, G., Li, J., Bi, J., Zhao, J. \& Bu, R. (2013). Spatial distribution and ecotoxicological risk assessment of heavy metals in surface sediments of the southern Bohai Bay, China, Environmental Science and Pollution Research, 20, pp. 4099-4110.

Huang, J., Ge, X. \& Wang, D. (2012). Distribution of heavy metals in water column, suspended particulate matters and the sediment under hydrodynamic conditions using an annular flume, Journal of Environmental Sciences, 24, pp. 2051-2059.

Ibragimow, A., Walna, B. \& Siepak, M. (2013). Physico-chemical parameters determining the variability of actually and potentially available fractions of heavy metals in fluvial sediments of the middle Odra river, Archives of Environmental Protection, 39, 2, pp. 3-16.

Jabłońska, M., Kostecki, M., Szopa, S., Łyko, A. \& Michalski, R. (2012). Speciation of inorganic arsenic and chromium forms in selected water reservoirs of Upper Silesia, Ochrona Środowiska, 3, pp. 25-32. (in Polish)

Jabłońska-Czapla, M., Szopa, S., Grygoyć, K., Łyko, A. \& Michalski, R. (2014). Development and validation of HPLC-ICP-MS method for the determination inorganic $\mathrm{Cr}$, As and $\mathrm{Sb}$ speciation forms and its application for Pławniowice reservoir (Poland) water and bottom sediments variability study, Talanta, 120 , pp. 475-483.

Jabłońska-Czapla, M., Szopa, S. \& Rosik-Dulewska, Cz. (2014). Impact of mining dump on the accumulation and mobility of metals in the Bytomka river sediments, Archives of Environmental Protection, 40, 2, pp. 3-19.

Kajak, Z. (1998). Hydrobiology-limnology, Ecosystems of inland waters, Wydawnictwo Naukowe PWN, Warszawa 1998. (in Polish)

Kajak, Z., Kacprzak, K. \& Polkowski, R. (1965). Tubular bottom sampler. Ekologia Polska, Ser B, 11, pp. 159-165. (in Polish)

Karbassi, A.R., Torabi, F., Ghazban, F. \& Ardestani, M. (2011). Association of trace metals with various sedimentary phases in dam reservoirs, International Journal of Environmental Science and Technology, 8, pp. 841-852.

Korfali, S.I., Jurdi, M. \& Davies, B.E. (2006). Variation of metals in bed sediments of Qaraaoun reservoir, Lebanon, Environmental Monitoring and Assessment, 115, pp. 307-319.

Kostecki, M. (2007). Bioaccumulation of heavy metals in selected elements of trophic chain of anthropogenic reservoirs in the aspect of environmental protection and economical function, Institute of Environmental Engineering of the Polish Academy of Sciences, Works \& Studies, 71, pp. 87. (in Polish)

Kostecki, M. \& Kowalski, E. (2007). Spatial arrangement of heavy metals in the dam-reservoir sediments in the conditions of anthropomixion, Archives of Environmental Protection, 3, pp. 67-81.

Leńczowska-Baranek, J. (1996). The Łączany Weir as a geochemical barrier in the migration of heavy metals, Applied Geochemistry, 11, pp. 223-238.

Li, F., Zhang, H., Meng, X., Chen, L. \& Yin, D. (2012). Contamination by persistent toxic substances in surface sediment of urban rivers in Chaohu City, China, Journal of Environmental Sciences, 24, pp. 1934-1941.

Ligęza, S. \& Smal, H. (2002). Differentiation of $\mathrm{pH}$ and texture in bottom sediments of Zemborzycki dam reservoir, Acta Agrophysica, 70, pp. 235-245. (in Polish)

Ligęza, S., Smal, H. \& Bielińska, E.J. (2004). Total content of Cd, $\mathrm{Cr}, \mathrm{Pb}, \mathrm{Zn}$ and their horizontal differentiation in bottom sediments of dam reservoir "Zalew Zemborzycki" near Lublin, SE Poland, Chemia i Inżynieria Ekologiczna, 11, pp. 621-627.

Loska, K. \& Wiechuła, D. (2003). Application of principal component analysis for the estimation of source of heavy metal contamination in surface sediments from the Rybnik reservoir, Chemosphere, 51, pp. 723-733.

MacDonald, D.D., Ingersoll, C.G. \& Berger, T.A. (2000). Development and Evaluation of consensus-based sediment quality guidelines for freshwater ecosystems, Archives of Environmental Contamination and Toxicology, 39, pp. 20-31.

Maciejczak, B. \& Czerwik-Marcinkowska, J. (2010). Macrophytes, cyanobacteria and algae of the "Brodzkie Lake" in the Małopolska Upland - Southern Poland - preliminary study, Roczniki Akademii Rolniczej w Poznaniu, CCCLXXXIX, 14, pp. 67-76. (in Polish)

Manasreh, W., Hailat, I. \& El-Hasan, T.M. (2010). Heavy metal and anionic contamination in the water and sediments in Al-Mujib reservoir, central Jordan, Environmental Earth Sciences, 60, pp. 613-621.

Marszałek, M. \& Banasiuk, R. (2011). Water legal study for the special use of the Bystrzyca River water for the Zalew Zemborzycki reservoir in the range of water damming and retention, Warsaw 2011, pp. 1-103. 
Misztal, M. \& Smal, H. (1980). Some chemical and physical properties submerged soils of the Zemborzyce dam reservoir, Soil Science Annual, 3, pp. 253-262.

RZGW (Regional Water Management Authority in Warsaw). (http// www.warszawa.rzgw.gov.pl/lewe_menu-utrzymanie_wod_i urzadzen_wodnych-wykaz_administrowanych-obiektowzbiornik_wodny_brody_ilzeckie.html (02.04.2014))

Rosińska, A. \& Dąbrowska, L. (2011). PCBs and heavy metals in water and bottom sediments of the Kozłowa Góra dam reservoir, Archives of Environmental Protection, 37, pp. 61-73.

Salomons, W. \& Förstner, U. (1984). Metals in the Hydrocycle, Springer-Verlag Berlin Heildelberg, New York, Tokyo 1984.

Sarà, G. (2009). Variation of suspended and sedimentary organic matter with depth in shallow coastal waters, Wetlands, 29, pp. 1234-1242.

Smal, H., Ligęza, S., Baran, S. \& Wójcikowska-Kapusta, A. (2015). Quantity and quality of organic carbon in bottom sediments of two upland dam reservoirs in Poland, Environment Protection Engieneering, 41, pp. 95-110.

Smal, H., Ligęza, S., Baran, S., Wójcikowska-Kapusta, A. \& Obroślak, R. (2013). Nitrogen and phosphorus in bottom sediments of two small dam reservoirs, Polish Journal of Environmental Studies, 32, pp. 1479-1489.

Smith, S.L., MacDonald, D.D., Keenleyside, K.A., Ingersoll, G.G. \& Field, J. (1996). A preliminary evaluation of sediment quality assessment values for freshwater ecosystems, Journal of Great Lakes Research, 22, pp. 624-638.

Sojka, M., Siepak, M. \& Gnojska, E. (2013). Assessment of Heavy
Metal Concentration i Bottom Sediments of Stare Miasto Pre-dam Reservoir on the Powa River, Annual Set The Environment Protection, 15, pp. 1916-1928. (in Polish)

Thornton, J., Steel, A. \& Rast, W. (1996). Chapter 8 - Reservoirs, in: Water quality assessments - a guide to use of biota, sediments and water in environmental monitoring $\left(2^{\text {nd }} E d\right)$, Chapman D. (Ed.), Spon Press Taylor \& Francis Group 1996.

Wang, C., Liu, S., Zhao, Q., Deng, L. \& Dong, S. (2012). Spatial variation and contamination assessment of heavy metals in sediments in the Manwan Reservoir, Lancang River, Ecotoxicology and Environmental Safety, 82, pp. 32-39.

Wang, G.,A,Y., Jiang, H., Fu, Q. \& Zheng, B. (2015). Modeling the source contribution of heavy metals in surficial sediment and analysis of their historical changes in the vertical sediments of a drinking water reservoir, Journal of Hydrology, 520, pp. 37-51.

Zhang, R., Zhang, F., Ding, Y., Gao, J., Chen, J. \& Zhou, L. (2013). Historical trends in the anthropogenic heavy metal levels in the tidalflat sediments of Lianyungang, China, Journal of Environmental Sciences, 25, pp. 1458-1468.

Zhao, Q., Liu, S., Deng, L., Dong, S. \& Wang, C. (2013). Longitudinal distribution of heavy metals in sediments of a canyon reservoir in Southwest China due to dam construction, Environmental Monitoring and Assessment, 185, pp. 6101-6110.

Zhu, X, Ji, H., Chen, Y., Ciao, M. \& Tang, L. (2013). Assessment and sources of heavy metals in surface sediments of Miyun Reservoir, Beijing, Environmental Monitoring and Assessment, 185, pp. 6049-6062.

\title{
Rozkład przestrzenny i ocena ryzyka metali ciężkich w osadach dennych dwóch małych zbiorników zaporowych (południowo-wschodnia Polska)
}

\begin{abstract}
Streszczenie: Badano osady dwóch zbiorników zaporowych w SE Polsce - Zalewu Zemborzyckiego (ZZ) i zbiornika Brody Iłżeckie (BI). W obydwu zbiornikach osady pobrano w transektach prostopadłych do linii brzegowej, w dopływie rzeki oraz przy zaporze czołowej. Oznaczono całkowitą zawartość $\mathrm{Mn}, \mathrm{Zn}, \mathrm{Pb}, \mathrm{Cd}, \mathrm{Cu}, \mathrm{Cr}$ i Ni metodą ICP-EAS po zmineralizowaniu próbki w mieszaninie stężonego kwasu $\mathrm{HNO}_{3}$ i $\mathrm{HClO}_{4}$. Przeprowadzono analizę statystyczną wyników: zakresy, wartości średnie, współczynnik zmienności, mediana, skośność rozkładu. Do oceny różnic między średnimi dla transektów zastosowano test Tukey’a z wyznaczeniem najmniejszej istotnej różnicy (NIR). Opracowano mapy rozkładu przestrzennego metali oraz oceniono jakość osadów wg kryterium geochemicznego i ekotoksykologicznego. Stwierdzono różnice między zbiornikami pod względem zawartości metali ciężkich i ich rozmieszczenia przestrzennego w osadach. W osadach $\mathrm{ZZ}$ zawartość metali kształtowała się na poziomie tła geochemicznego $(\mathrm{Zn}, \mathrm{Cr})$, osadów słabo $(\mathrm{Cd}, \mathrm{Cu}, \mathrm{Ni})$ lub miernie zanieczyszczonych $(\mathrm{Pb})$. Zawartość metali w osadach BI była do ośmiu razy większa w porównaniu z osadami ZZ. Ponadto, osady zbiornika BI wykazały większą zmienność zawartości metali niż osady ZZ, co wynikało z zabiegu bagrowania, przeprowadzonego w jego części. Zawartość metali w osadach części bagrowanej była ok. 2-5 razy mniejsza niż w niebagrowanej, co wskazuje, że po zabiegu bagrowania ich akumulacja była niewielka. Zawartości $\mathrm{Zn}, \mathrm{Pb}$ i Cd w części niebagrowanej BI były na poziomie osadów zanieczyszczonych i przekroczyły wartości PEL (ang. probable effects level). W ZZ największa akumulacja metali w osadach wystąpiła w górnej części zbiornika oraz przy zaporze czołowej, a najmniejsza w jego środkowej części. W BI dolny odpływ wody ze zbiornika spowodował zmniejszenie zawartości metali w osadach przy zaporze czołowej w porównaniu z innymi osadami części niebagrowanej. Wyniki badań wskazują, że w małych i płytkich zbiornikach zaporowych akumulacja metali ciężkich zależy od czynników takich jak: pierwotny nurt rzeki, głębokość zbiornika, falowanie wody, kształt zbiornika (przewężenia, zatoczki/ zatoki), a także od typu odpływu wody.
\end{abstract}

